Discussion Paper No. 10-075

\title{
Voluntary Giving and Economic Growth: Time Series Evidence for the US
}

Friedrich Heinemann

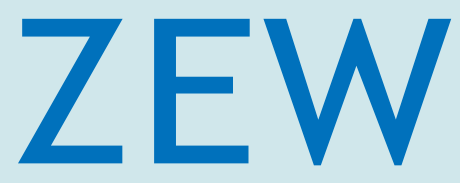

Zentrum für Europäische Wirtschaftsforschung $\mathrm{GmbH}$

Centre for European

Economic Research 
Discussion Paper No. 10-075

\title{
Voluntary Giving and Economic Growth: Time Series Evidence for the US
}

\author{
Friedrich Heinemann
}

Download this ZEW Discussion Paper from our ftp server:

ftp://ftp.zew.de/pub/zew-docs/dp/dp10075.pdf

Die Discussion Papers dienen einer möglichst schnellen Verbreitung von neueren Forschungsarbeiten des ZEW. Die Beiträge liegen in alleiniger Verantwortung der Autoren und stellen nicht notwendigerweise die Meinung des ZEW dar.

Discussion Papers are intended to make results of ZEW research promptly available to other economists in order to encourage discussion and suggestions for revisions. The authors are solely responsible for the contents which do not necessarily represent the opinion of the ZEW. 


\section{Non-technical Summary}

Given the substantial consolidation pressure in tax dependent government budgets, voluntary contributions play an increasing role in the financing of activities related to welfare, culture or education. There is hope that voluntary giving may at least partially become a stable substitute for tax financing. Tax revenues are highly sensitive to economic growth and the business cycle. Hence, a first question arises as to which extent voluntary giving is equally sensitive to the business cycle. Insofar it is less elastic compared to taxation it might contribute to a more stable financing of public goods over the business cycle. A second question relates to the long-run impact of trend growth on giving and to the extent to which giving benefits from the augmentation of an economy's economic resources. If the long-run growth elasticity of aggregate giving is large, this result would point to a yielding source of finance whose importance can be expected to grow with an expanding economy.

Therefore, this paper analyzes the sensitivity of aggregate giving to both business cycle developments and trend growth. In this respect it contributes to fill a blank spot in the charitable giving literature. The study applies time series modeling which follows approaches developed to analyze the tax revenue-growth-nexus. This cointegration modeling takes account of a possible long-run link between income and giving which may temporarily interfere with cyclical fluctuations. The resulting error correction specification allows disentangling the short-run (business cycle related) from the long-run (potential growth related) income elasticity. These tools are applied to data on US giving for a forty-year period (1968-2008) for the aggregate of total giving and for its subcomponents (individual, corporate, foundation giving, and charitable bequests).

With tax revenues as a point of reference, US giving constitutes indeed a relatively stable source of revenue. Total giving is characterized by a business cycle volatility which is comparable to the moderate one of indirect taxes. However, this overall finding is composed of the respective sub-components' very different short-run GDP-elasticities. Whereas individual and in particular corporate giving is quite sensitive to cyclical fluctuations, foundation giving and charitable bequests tend to stabilize total giving over the business cycle. This cyclical buffer function of charitable bequests and foundation giving has so far been overlooked in the literature.

The results for nominal (and even more for real) long-run growth also paint a favorable picture: giving benefits in or even above proportion from an augmentation of economic resources in an economy. This holds for foundation giving in particular which is highly elastic to nominal and real long-run growth.

The comparison of the finding to the well researched micro-elasticities points to the possible existence of social multipliers in the case of US giving: the macro estimates for the income elasticities lie in the upper band of the micro-estimates. This is consistent with a social multiplier view according to which individual giving is mutually reinforcing. 


\section{Das Wichtigste in Kürze}

Angesichts des Konsolidierungsbedarfs in steuerfinanzierten öffentlichen Budgets spielen freiwillige Spenden eine wachsende Rolle in der Finanzierung sozialer, kultureller und bildungsbezogener Aktivitäten. Es besteht die Hoffnung, dass private Spenden zumindest teilweise die Steuerfinanzierung als stabile Finanzierungsquelle substituieren können. Steuereinnahmen reagieren sensitiv auf Wirtschaftswachstum und konjunkturelle Schwankungen. Damit stellt sich zunächst die Frage, bis zu welchem Grad auch Spenden sensitiv auf Konjunkturschwankungen reagieren. Insoweit sie weniger elastisch als Steuereinnahmen reagieren, können sie zu einer stabileren Finanzierung öffentlicher Güter über den Konjunkturzyklus beitragen. Eine weitere Frage betrifft den Einfluss langfristigen Wachstums auf das Spendenaufkommen und das Ausmaß, in dem das Aufkommen von der Zunahme der Ressourcen einer Volkswirtschaft profitiert. Mit einer höhen Wachstumselastizität des aggregierten Spendenaufkommens wäre zu erwarten, dass die Bedeutung der Spendenfinanzierung mit einer Ökonomie wächst.

Dieses Papier analysiert somit die Sensitivität des aggregierten Spendenaufkommens in Bezug sowohl auf konjunkturelle Schwankungen als auch auf Trendwachstum. Zur Anwendung kommen Zeitreihenmodelle, wie sich auch für Analysen des Zusammenhangs zwischen Steuereinnahmen und Wachstum Verwendung finden. Die Modellierung als Kointegrationsbeziehung erlaubt es, eine Langfristbeziehung zu berücksichtigen, die von kurzfristigen konjunkturellen Einflüssen überlagert ist. Das resultierende Fehler-Korrektur-Modell ermöglicht es, kurzfristige (konjunkturbezogene) Einkommenselastizitäten von den langfristigen (trendwachstumbezogenen) Elastizitäten zu unterscheiden. Das Modell wird auf US-Daten für einen vierzigjährigen Zeitraum (1968-2008) angewendet. Einbezogen wird das Spendenaufkommen insgesamt und seine Komponenten: individuelle Spenden, Unternehmensspenden, Stiftungsspenden und Erbschaften für wohltätige Zwecke.

Im Vergleich zum Referenzfall des Steueraufkommens, stellt das US-Spendenaufkommen tatsächlich eine relative stabile Finanzierungsquelle dar. Das Spendenaufkommen insgesamt ist durch eine konjunkturelle Volatilität gekennzeichnet, die derjenigen der indirekten Steuern entspricht. Hinter diesem Gesamtbild verbergen sich allerdings sehr unterschiedliche Kurzfristelastizitäten der verschiedenen Spenden-Komponenten. Während Individual- und Unternehmens-Spenden recht sensitiv auf konjunkturelle Schwankungen reagieren, stabilisieren Spenden von Stiftungen und durch Erbschaften das aggregierte Spendenaufkommen über den Konjunkturzyklus. Diese Pufferfunktion von wohltätigen Vermächtnissen und Stifungsfinanzierungen ist bislang in der Literatur zu wenig beachtet worden.

Die Ergebnisse in Bezug auf das nominale (und noch starker das reale) Langfrist-Wachstum ergeben ebenfalls ein vorteilhaftes Bild: Das Spendenaufkommen profitiert überproportional von der Vermehrung der ökonomischen Ressourcen einer Volkswirtschaft. Dies gilt besonders ausgeprägt für die Stiftungsfinanzierung, die sehr elastisch auf nominales und reales Wachstum reagiert. 
Der Vergleich dieser Resultate mit den Elastizitäten der mikroökonometrischen SpendenLiteratur deutet auf die Existenz sozialer Multiplikatoren für das US-Spendenverhalten hin: Die Makro-Elastizitäten sind im oberen Bereich des aus den Mikro-Studien bekannten Bandes. Dieser Befund ist konsistent mit der Existenz sozialer Multiplikatoren und der wechselseitigen Verstärkung individueller Spendenaktivitäten. 


\title{
Voluntary Giving and Economic Growth: Time Series Evidence for the US
}

\author{
Friedrich Heinemann (ZEW Mannheim)
}

October 2010

\begin{abstract}
:
This study analyzes the sensitivity of US giving to both business cycle fluctuations and trend growth. With tax revenues as a point of reference, US giving constitutes a relatively stable source of revenue. Total giving is characterized by a business cycle volatility which is comparable to the moderate one of indirect taxes. However, this overall finding is composed of the respective sub-components' very different short-run GDP-elasticities. Individual and, to an even larger extent, corporate giving is quite sensitive to cyclical fluctuations. By contrast, foundation giving and charitable bequests tend to stabilize total giving over the business cycle. The macro estimates for the income elasticities lie in the upper band of the well researched micro-estimates. This is consistent with a social multiplier view according to which individual giving is mutually reinforcing.
\end{abstract}

JEL Classification Code: H27, H41, C22

Keywords: Charitable giving, social multiplier, error-correction-model

Valuable research assistance from Christoph Schleibaum is gratefully acknowledged. I thank Marcus Kappler and Sarah Borgloh for helpful comments, and Sharon Bond, Giving USA Foundation, for providing long-run data on US giving.

Friedrich Heinemann

Centre for European Economic Research (ZEW)

L7, 1

68161 Mannheim

Germany

++49-621-1235 149

Heinemann@zew.de 


\section{Introduction}

Given the substantial consolidation pressure in tax dependent government budgets, voluntary contributions play an increasing role in the financing of activities related to welfare, culture or education. There is hope that giving may at least partially become a stable substitute for tax financing. The financing of public or semi-public activities through voluntary giving instead of coercive taxation has some obvious advantages: From an efficiency point of view it should be superior since voluntary giving is by definition not compulsory but the result of the individual's optimizing decision. The voluntary donor is free to choose among beneficiaries and giving purposes while tax payments as such do not offer any impact on provision of public goods. Hence, shifting financing from taxation to voluntary giving clearly fosters a supply of services with a better fit to the preferences of the citizens. Furthermore, while a "warm glow" may accompany the act of giving (Andreoni, 1990), paying taxes is rarely associated with a feeling of pleasure. On the contrary, the experimental literature points to the phenomenon of "tax aversion" where the labeling of a monetary charge as "tax" arouses a negative reaction (McCaffery and Baron, 2005).

This being said, this paper deals with a further potential advantage of giving over paying taxes: the possibility that giving may be a more stable source of revenues than taxes over the business cycle. Tax revenues are highly sensitive to economic growth and the business cycle. Economic downturns regularly put government budgets under stress - a phenomenon highly relevant in the historic global recession following the financial crisis of 2008. Hence, a first question arises as to which extent voluntary giving is equally sensitive to the business cycle. Insofar it is less elastic compared to taxation it might contribute to a more stable financing of public goods over the business cycle. In this case, this kind of financing would not only be more efficient but also be more reliable in a volatile economic environment. A second question relates to the long-run impact of trend growth on giving and to the extent to which giving benefits from the augmentation of an economy's economic resources. If the long-run growth elasticity of aggregate giving is large, this result would point to a yielding source of finance whose importance can be expected to grow over the decades.

Therefore, this paper analyzes the sensitivity of aggregate giving to both business cycle developments and trend growth. In this respect it contributes to fill a blank spot in the charitable giving literature. While there is a wealth of microeconomic studies on the determinants of charitable giving, approaches with a rather macroeconomic perspective are largely absent. 
The study applies time series modeling which follows approaches developed to analyze the tax revenue-growth-nexus. The cointegration modeling takes account of a possible long-run link between income and giving which may temporarily interfere with cyclical fluctuations. The resulting error correction specification allows disentangling the short-run (business cycle related) from the long-run (potential growth related) income elasticity. It thus allows assessing both the cyclical volatility of giving and its long-run link to trend growth. This modeling is applied to data on US giving for a forty-year period (1968-2008) for the aggregate of total giving and for its subcomponents (individual, corporate, foundation and charitable bequests). Robustness tests are applied to take account of the specificities of the sub-components, such as the impact of (changing) tax incentives on individual or corporate giving or to examine the impact of an inflationary environment. To the best of our knowledge this is the first approach to apply modern time series modeling to the link between giving aggregates and economic growth. Earlier literature on the time path of US giving as Clotfelter (1985b for corporate giving, or cited in there) do not yet pay attention to problems of potential spuriousness of results of regressions based on non-stationary time series or to the differentiation between the impact of the business cycle versus long-run growth.

The results reveal that the aggregate of US giving has a short-run GDP elasticity of around one which is comparable to the elasticity of indirect taxes. However, the sub-component GDP elasticities differ substantially: Whereas individual and in particular corporate giving is quite sensitive to cyclical fluctuations, foundation giving and charitable bequests tend to stabilize total giving over the business cycle. The long-run elasticity indeed points to a yielding source of finance with a growth rate exceeding that of GDP.

The paper's structure is as follows: In section 2 the two key points of reference in the literature are summarized which relate to microeconometric findings and macro-estimates. Section 3 introduces the data and describes the tax environment of US giving and its variation over time which has to be taken into account in the testing. Subsequently, in section 4 the dynamic modeling together with the econometric testing is presented, followed by the overall conclusions. 


\section{Income elasticities of giving and tax revenues}

The analysis can be related to two points of reference, first to the income elasticity of tax revenues as identified in the macroeconomic time series literature and second to the individual income and price elasticity of giving as identified in micro-econometric studies. The former is the point of reference with respect to methodology and in order to judge how voluntary giving performs relative to taxation with respect to its growth elasticity. The latter gives a first indication which elasticities might be plausible on an aggregate level.

\section{Macroeconomic income elasticities of tax revenue}

Analytically, different approaches exist to quantify the income elasticity of tax revenues (van den Noord, 2000): One option is to run a regression with tax proceeds as the dependent and a measure of output as the explanatory variable. The estimation coefficient for output (dependent and independent variables as logarithms) would then constitute the estimation of $\varepsilon_{\mathrm{T}}$, the income elasticity of tax revenues. The difficulty of this approach is, however, to disentangle growth driven fluctuations of tax revenues from those caused by changing tax laws. Hence, policy variables have to be included among the explanatory variables.

A second option is based on a two-step procedure (van den Noord, 2000; Girouard and André, 2005). The income elasticity of tax revenues, $\varepsilon_{\mathrm{T}} \mathrm{Y}$, is derived as the product of two components: the elasticity of tax proceeds with respect to the tax base, $\varepsilon_{\mathrm{T} \mathrm{TB}}$, and the elasticity of the tax base with respect to GDP, $\varepsilon_{\mathrm{TB}}$.

$$
\varepsilon_{T Y}=\varepsilon_{T T B} * \varepsilon_{T B Y}
$$

While the income elasticity of the tax base can only be determined econometrically, the tax base elasticity of tax revenues is a function of the tax system's features. For a purely proportionate type of tax the value is unity, for a progressive (regressive) tax the elasticity is above (below) one. Note that with a non-proportionate type of tax, it is necessary to have information on the income distribution in addition to knowledge of the tax system to derive an aggregate measure for the elasticities.

This second option based on a two-step procedure is the common one in the context of the calculation of cyclically adjusted government budget balances. Table 1 summarizes the cur- 
rent elasticities employed by the OECD to adjust for the cyclical component of tax revenues in the case of the US, the country of examination. According to these results social security contributions are rather inelastic whereas both income and corporate tax revenues fluctuate strongly in the course of the business cycle and tend to induce deficits in a cyclical downswing.

These tax revenue elasticities offer the first point of reference when it comes to evaluating the giving elasticities. The latter are harder to identify, since giving is not driven by a well defined tax tariff but by individuals’ optimizing behavior. Section 4 returns to this issue.

Table 1: US tax elasticities in OECD approach of cyclical adjustment

\begin{tabular}{|l|c|c|c|c|}
\hline & Income tax $^{+}$ & Indirect tax $^{++}$ & $\begin{array}{c}\text { Social security } \\
\text { contribution }^{+}\end{array}$ & Corporate tax $^{+++}$ \\
\hline$\varepsilon_{\mathrm{TB} \mathrm{Y}}$ & 0.7 & 1.0 & 0.7 & 1.5 \\
\hline$\varepsilon_{\mathrm{T} \mathrm{TB}}$ & 1.9 & 1.0 & 0.9 & 1.0 \\
\hline$\varepsilon_{\mathrm{T} \mathrm{Y}}$ & 1.3 & 1.0 & 0.6 & 1.5 \\
\hline
\end{tabular}

Source: (Girouard and André, 2005); ${ }^{+}$tax base measure: wage bill; ${ }^{++}$by assumption “following a common practice .. and given the econometric difficulties in finding consistent estimates across countries” (Girouard and André, 2005: p. 17); ${ }^{+++}$tax base measure: profits.

\section{Elasticity of giving in the micro-econometric literature}

In contrast to the virtually non-existent macroeconometric approaches, the micro-strand of the literature on the drivers of giving is rich. Two elasticities are the focus of this literature: both the income and the (tax) price elasticity of charitable giving. This reflects the insight that voluntary giving should react both to the disposable income and its tax price. Without any tax incentives the price of giving one Dollar is equal to one. With giving deductible from taxable income, this reduces the price of giving to one minus the marginal income tax rate (Steinberg, 1990) and should affect behavior. 
Clotfelter (1985a) and Steinberg (1990) offer early literature reviews. Clotfelter reports an income elasticity of giving of 0.7 as typical of estimates from earlier studies. Steinberg provides a meta-analysis about the income elasticity by surveying 24 studies which estimate the impact of changes in after-tax income on personal donations in the US and Canada. The elasticities assessed were all positive, ranging from 0.02 to 2.68 (see Figure 1), whereas the majority of observations is smaller than 1 , clustering between 0.5 and 0.6 with a mean of 0.61 (standard deviation 0.43). With respect to price elasticity the results are more disparate (see Figure 2): According to the Steinberg meta-analysis, the range is from -4.8 to +2.9 with a mean at -1.06 (standard deviation 1.29). A more recent meta-analysis of Peloza and Steel (2005) estimates the weighted mean of the price elasticity of giving to be -1.44 , with a standard deviation of 1.21. This literature is far advanced and covers numerous differentiations such as the particular elasticity of different charitable purposes (Schiff, 1990) or the price responsiveness of itemizers versus non-itemizers (Duquette, 1999). Methodological refinements address measurement errors in tax data related to tax evasion (Joulfaian and Rider, 2004) or evaluate survey-based versus tax-data-based approaches (Tiehen, 2001). While the earlier studies were confined to cross-sectional data from household surveys or individual tax returns, the more recent ones use panel data, largely from tax returns (such as Auten, Sieg and Clotfelter, 2002). Further extensions also apply similar approaches to corporate giving (Clotfelter, 1985b; Auten, Cilke and Randolph, 1992) and charitable bequests (Joulfaian, 1991; Joulfaian, 2000). Increasingly, this literature also spreads to non-Anglo-Saxon countries, such as Germany (Borgloh, 2008).

There are two reasons why these micro-elasticities do not immediately translate into macroelasticities without modification. The link between aggregate income growth on the one hand and aggregate giving on the other hand does not only depend on the individuals' reactions. It is also affected by shifts in the distribution of the population across income classes and across other characteristics which can be controlled for in the micro-studies but not in macroapproaches. Even for long-run time series the low number of observations precludes a comprehensive control. Thus, the ceteris paribus assumption with respect to socio-economic or cultural factors, which holds for well designed micro-studies, is not valid for aggregate approaches. Beyond that aspect, a more subtle explanation can drive a wedge between microand macro-elasticities: In their theory of "social multipliers”, Glaeser et al. (2003) point to the fact that aggregate behavioral reactions may differ from reactions measured on the micro level due to social interactions: If one person's actions influence his neighbor's behavior, microreaction may reinforce each other. They find evidence for this for the impact of education on 
wages and demographics on crime. Alesina, Glaeser and Sacerdote (2005) argue that social multipliers can explain the high tax elasticity of labor supply on the aggregate level which contrasts with the findings of micro-studies: Since the individual utility from leisure consumption is a function of one's friends' and relatives' leisure consumption, social relations will tend to increase elasticities above the level detected for individual behavior in isolation. It is obvious that this idea of a social multiplier could be relevant in the context of giving as well, as also some hints in the micro-literature suggest: In their analysis of a mail fundraising campaign Frey and Meier (2004) show that social information on the generosity of others increases the willingness to give. For survey data Feldstein and Clotfelter (1976) do not and Andreoni and Scholz (1998) do find a small impact of giving of the peer group on own giving. These considerations and blurred micro-results underline the importance of accompanying macro-studies: Differences between macro- and micro-approaches can serve as an indicator for the existence and empirical relevance of social multipliers of giving.

Figure 1: Frequency distribution of income elasticities of charitable giving

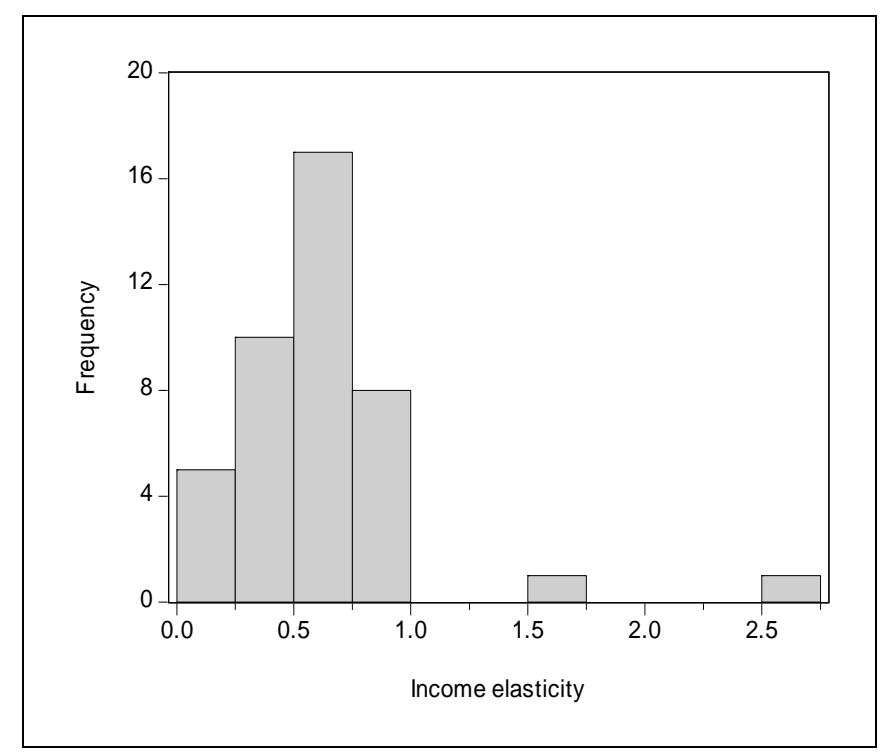

Results on income elasticities of giving from meta-study (Steinberg, 1990). Includes 47 results from 24 studies, 21/3 refer to US/UK data. 


\section{Figure 2: Frequency distribution of price elasticities of charitable giving}

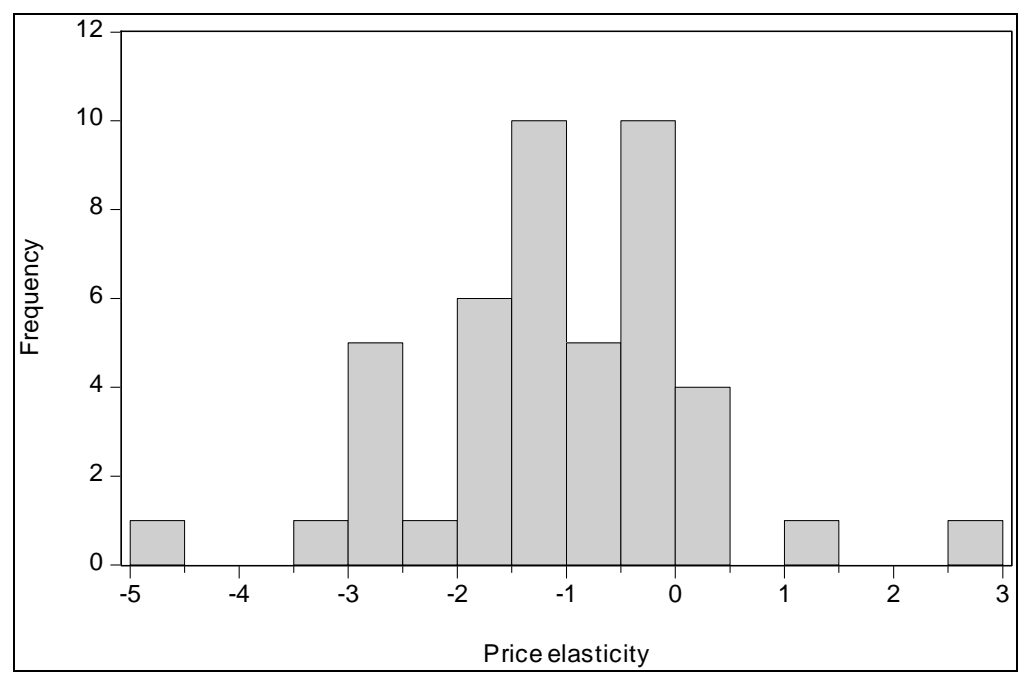

Results on income elasticities of giving from meta-study (Steinberg, 1990). Includes 47 results from 24 studies, 21/3 refer to US/UK data.

\section{Data and tax incentives}

For the analysis a database of US giving is used which was provided by the Giving USA Foundation. ${ }^{1}$ This database currently provides time series for a period of 41 years (1968 to 2008) on total giving and four subcomponents: giving of individuals, corporations, foundations and charitable bequests. ${ }^{2}$ Figure 3 depicts the time series together with US GDP. US giving is dominated by individual giving which amounts to three quarters of the total aggregate for the most recent data. Rank 2 is foundation giving with a share of 13 per cent in the year 2008, followed by bequests (7 per cent) and the corporate sector ( 5 per cent). In the course of the four decades under scrutiny, some shifts in the composition of giving have occurred. The importance of foundation giving has almost doubled compared to its average

${ }^{1}$ According to information from Giving USA the data are based on different sources: tax data from corporations, tax data from income tax itemizers and data US charities have to provide for the Internal Revenue Service annually (through IRS form 990 which has to be submitted by tax-exempt and non-profit organizations).

${ }^{2}$ Note that this data structure implies some double counting (Clotfelter, 1985c): Foundations accumulate their wealth from voluntary giving and use this wealth and its yields to give for the foundations' purposes. This intermediating function of foundation affects the time path of giving aggregate so that an inclusion of foundation giving is important in a study which has a focus on aggregate giving dynamics. 
share in the 1970s. The reversed development occurred for the share of individual giving which, initially dominated total giving even more.

The visual inspection also reveals that there is a link of giving to GDP growth although the evolution of giving aggregates has not the smoothness of GDP. One reason may be a varying tax incentive environment. As shown by the microeconometric literature, individual giving cannot be understood satisfactorily without taking into account the price of giving determined by tax advantages. However, these tax incentives vary over time.

Figure 3: Giving in the US 1968-2008

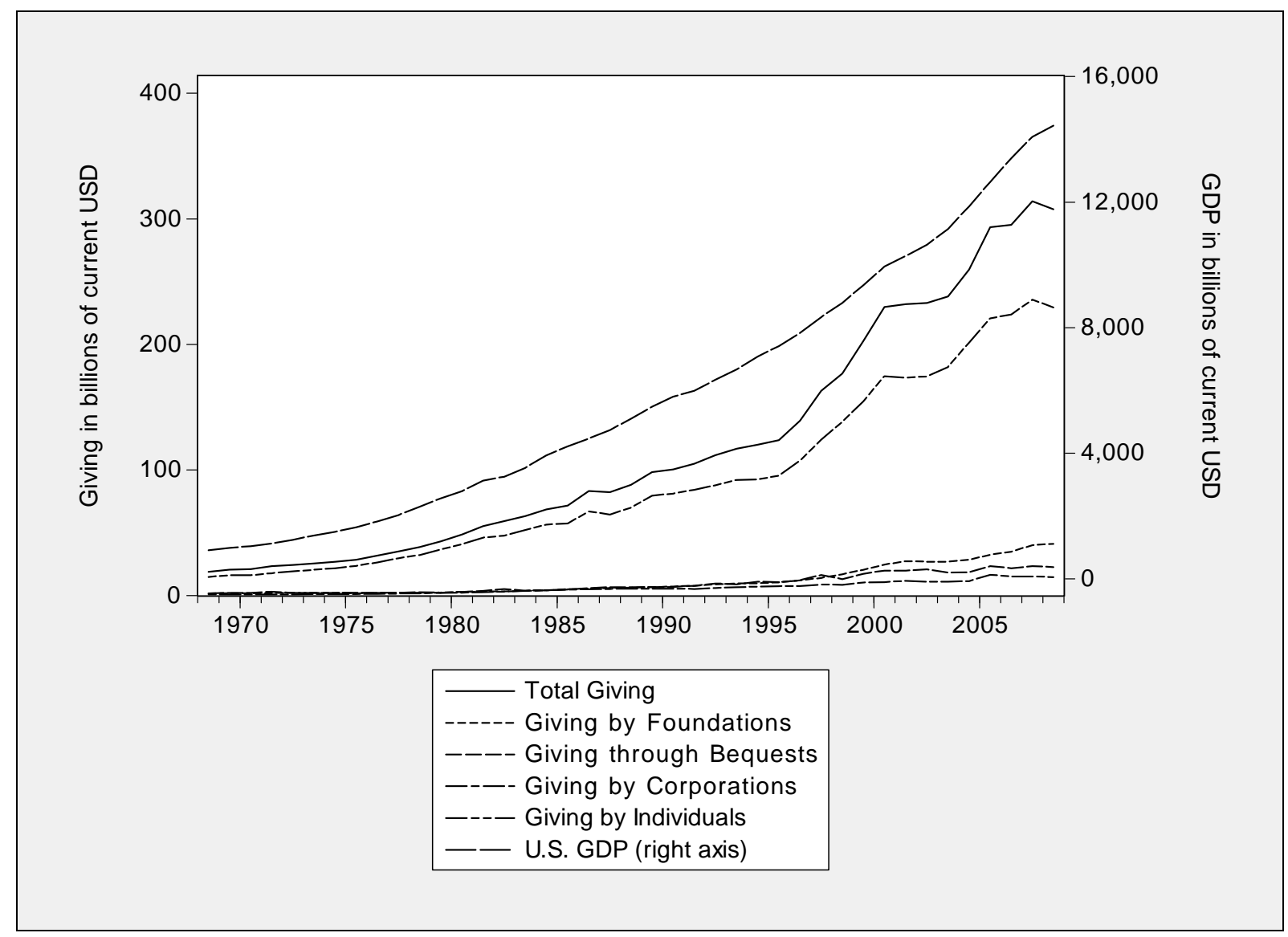

Source: Giving USA Foundation

While the system parameters change, the current US system of tax incentives for charitable giving has been in place over the whole sample period and long before, dating back to 1917 (Randolph, 2005). Since then, individual federal taxpayers have been allowed to deduct gifts 
to charitable and certain non-profit organizations in the US from their taxable income. The condition is that taxpayers make their contributions to a qualified organization. Among those eligible are non-profit groups that are religious, charitable, educational, scientific, or literary in purpose, or that work to prevent cruelty to children or animals. The tax incentive was motivated to subsidize organizations that provide substitutes to government programs. The specific reason of the 1917 introduction was a tax increase. The deduction was intended to counterbalance disincentives of the higher tax burden for private charity. While it was first limited to individual taxpayers, corporations were also allowed a deduction starting in $1935 .{ }^{3}$ Hence, the system in place over the period under investigations sets particular incentives for individual and corporate giving. Similarly, the privileged treatment of charitable bequests under the estate tax dates back long before the sample starts: The modern estate tax was enacted in 1916 and charitable deductions were granted in 1918 (Jacobson, Raub and Johnson, 2007). Finally, the structural features of the tax treatment of foundations have also been stable for the period under scrutiny: the foundations are allowed to accumulate income without taxation and benefit on the revenue side from the preferential tax treatment of their donors in income and corporate tax schemes (Clotfelter, 1985c).

Given a stable basic incentive system in the period under investigation, the time series variation of the price of giving is determined by the tax level. It therefore depends on changes in tax tariffs in the case of individual giving (income tax rate), corporate giving (corporate tax rate) and charitable bequests (estate tax rate). Because the privileged tax treatment of foundations is independent from their payouts, there is no tax price calculus for foundations analogous to the one for individual and corporate giving or charitable bequests. In the empirical specification a simple tax price of giving proxy is employed, which is defined to be one minus the top marginal federal income tax rate (with data on tax rate history from National Taxpayers Union) for individual giving, one minus the (flat or top) corporate income tax rate (with data from OECD) for corporate giving and one minus the top estate tax (data from Jacobson, Raub and Johnson, 2007). The tax price construction is confined to the federal tax and ab-

\footnotetext{
${ }^{3}$ Further structural changes occurred since 1935 in the tax treatment of corporate giving (Boatsman and Gupta, 1996): In 1953, before the starting year of the sample, the "direct benefit doctrine" was given up, according to which corporate contributions were only deductible if they yielded a "direct benefit" in terms of a profit increase to the corporation. One structural break for the tax treatment of corporate giving, however, falls into the sample period: The Economic Recovery Tax Act of 1981 doubled the limit of deductable contributions from five to ten percent of net income before contributions.
} 
stract from state taxation. The time series variation is considerable: While top income tax rates amounted to 75 per cent in 1968, they declined to 28 per cent in the late eighties with a subsequently rising trend. Corporate income tax declined from 53 to a minimum of 34 per cent in 1988 with a subsequent slight rise. The top estate tax dropped from 77 (up to the year 1976) to 45 per cent in 2007. To cope with shifts in the distribution of income taxpayers other measures were employed, such as one minus the tax rate of an average income earner. However, this did not improve the significance of the tax price covariates in the subsequent regression.

\section{Dynamic modeling and estimation}

The methods developed to measure the growth related fluctuation of tax revenues are the natural starting point for the modeling of the GDP elasticity of voluntary giving. The two-step logic of the analytical problem as described in section 2 in the context of tax revenues remains valid. The aggregate income elasticity of giving, $\varepsilon_{\mathrm{G}} \mathrm{Y}$, can also be modeled as the product of two components: the elasticity of giving with respect to the "giving base" (the analogy to the tax base), $\varepsilon_{\mathrm{G} \mathrm{GB}}$, and the elasticity of the giving base with respect to aggregate income, $\varepsilon_{\mathrm{GB}} \mathrm{Y}$. The giving base resembles the tax base insofar as it is the economic aggregate from which resources are financed.

(2) $\varepsilon_{G Y}=\varepsilon_{G G B} * \varepsilon_{G B Y}$

Although the structure of (1) and (2) appears identical the highly different economic character of the first right-hand side elasticity must be emphasized. While in equation (1) this term is defined by the tax tariff it depicts a behavioral parameter in the context of giving which, by definition, describes a pattern of voluntary behavior and is not directly affected by deterministic and legally defined constraints. ${ }^{4}$ This difference also precludes any approach which would derive $\varepsilon_{\mathrm{G}}$ GB directly from system features. Instead, both $\varepsilon_{\mathrm{G}} \mathrm{GB}$ and $\varepsilon_{\mathrm{GB}}$ y have to be quantified econometrically. While it is desirable to disentangle the two right hand side elasticities it is

\footnotetext{
${ }^{4}$ Even for taxes one could argue that the link is not completely deterministic given the leeway of tax subjects to avoid or evade taxation.
} 
equally possible to estimate $\varepsilon_{G}$ Y directly in a one-step approach, if for example a sensible giving base is not available.

The estimation model is based on a flexible and general dynamic framework (Hendry, 1995, Ch. 7) which allows for different specifications that correspond to the time series properties of the included variable. For the one-step approach ${ }^{5}$, giving $(g$, logarithm) depends on both current and lagged values of income $(y$, logarithm) and an autoregressive term. The error term, $\mu_{t}$, represents non-systematic shocks on giving such as outstanding natural disasters which push giving temporarily:

$$
g_{t}=\beta_{0}+\beta_{1} y_{t}+\beta_{2} y_{t-1}+\beta_{3} g_{t-1}+\mu_{t}
$$

Rearranging terms of this autoregressive distributed lag specification results into

$$
\Delta g_{t}=\beta_{0}+\beta_{1} \Delta y_{t}+\left(\beta_{1}+\beta_{2}\right) y_{t-1}-\left(1-\beta_{3}\right) g_{t-1}+\mu_{t}
$$

with an equivalent error correction representation

$$
\Delta g_{t}=\beta_{0}+\beta_{1} \Delta y_{t}-\lambda\left[g_{t-1}-\phi y_{t-1}\right]+\mu_{t}
$$

where $\lambda=\left(1-\beta_{3}\right)$ and $\phi=\left(\beta_{1}+\beta_{2}\right) /\left(1-\beta_{3}\right)$.

The error correction representation is of crucial importance to disentangle the long-run income elasticity of giving from the short-run elasticity. Whereas $\beta_{1}$ represents the short-run elasticity related to a cyclical move of income, $\phi$ represents the long-run reaction. Hence, the dexter bracket term in (5) represents the divergence from the long-run equilibrium between giving and income, and $\lambda$ indicates the speed of adjustment to restore divergence from equilibrium. Note that an estimation of equation (4) is sufficient to derive estimates for both the short- and long-run elasticities in focus. While (4) describes the estimable specification for a two variable error correction it can easily be augmented to include a third variable which could be the tax price in addition to income as a driver of giving.

\footnotetext{
${ }^{5}$ The two-step approach is equivalent - the equivalent dynamic modelling can be applied to both steps: first to the link between income and the giving base and second to the link between the giving base and giving.
} 
This error correction modeling is a legitimate approach if the two (or more) time series included are characterized by certain characteristics. Time series estimations based on variables in levels require that dependent and independent variables are stationary. Otherwise meaningless spurious estimations are produced (Granger and Newbold, 1974). With non-stationary variables, the error correction approach is possible only if a long-run link indeed exists between the variables ${ }^{6}$, i.e. these variables are tied together through a cointegrating relationship. If the variables included are non-stationary (e.g. of order one) but no cointegration exists, the dynamic modeling must be limited to a specification based on first differences (which fulfill the stationarity requirements but do not assume a long-run link in levels).

Therefore, preparatory testing is needed which determines the order of integration of the time series involved and which reveals whether a cointegration relationship exists. Even though the available unit root and cointegration tests rarely produce unequivocal results they are indispensable to judge to which extent the described dynamic modeling is appropriate.

\section{Unit root and cointegration tests}

Table 2 summarizes the results of the Advanced Dickey Fuller (ADF) tests for the variables included in the analysis. The tests on the levels of all giving aggregates clearly indicate that the null hypothesis of non-stationarity cannot be rejected whereas the rejection is highly significant for the first differences. Hence, all giving aggregates can be treated as integrated of order one. The same results hold for GDP, the disposable income and the tax prices. Only the testing for corporate profits points to a possible stationarity of the level variable.

\footnotetext{
${ }^{6}$ This is only possible if the variables have the same order of integration.
} 
Table 2: ADF Tests for Unit Roots Results

\begin{tabular}{lcc}
\hline & $\begin{array}{c}\text { ADF test statistic } \\
\text { logarithmic levels }\end{array}$ & $\begin{array}{c}\text { ADF test statistic } \\
\text { first differences }\end{array}$ \\
\hline Giving & -1.01 & $-4.57^{* * *}$ \\
Total & -1.15 & $-4.31^{* * *}$ \\
Individual & 0.41 & $-7.44^{* * *}$ \\
Corporate & 0.99 & $-5.44^{* * *}$ \\
Foundations & -2.39 & $-2.39^{* * *}$ \\
Bequests & 1.14 & $-4.43^{* * *}$ \\
GDP & 1.03 & $-6.70^{* * *}$ \\
Disposable income & $-3.74^{* *}$ & $-4.32^{* * *}$ \\
Corporate profits & -1.35 & $-5.36^{* * *}$ \\
Tax price income tax & -2.34 & $-4.60^{* * *}$ \\
Tax price corporate tax & -1.94 & $-4.62^{* * *}$ \\
Tax price bequests &
\end{tabular}

Constant and time trend included as deterministic regressors; choice of lag length based on Schwartz criterion. $* * * / * * / *$ : Null hypothesis of non-stationarity can be rejected with significance level of 1/5/10 per cent.

The picture is less clear cut for cointegration tests whose results are presented in Table 3. Both the single equation Engle Granger test and the Johansen procedure point to the cointegration of GDP on the one hand and disposable income and corporate profits on the other hand (the giving bases with respect to individual and corporate giving). At least the Johansen test also supports cointegration for the link between all giving types and GDP or alternative giving bases with the exception of the link between bequests and GDP. But in this case the Engle Granger approach indicates cointegration. For three variable relationships including the measure of taxation the Johansen test is superior since single equation tests are less powerful for relationships of more than two variables. Here, individual giving, disposable income and the tax price appear to be tied together in a long-run cointegrating equation. The same holds for the relationship between corporate profits, the tax price of corporate giving and GDP or corporate profits. For the link between charitable bequests, GDP and the (estate) tax price the Johansen tests does not point to cointegration whereas the single equation test does. For total giving no three variable cointegration is supported which is not implausible given that taxes should not affect all sub-components of giving. Overall it appears legitimate to submit these relationships to an error correction testing procedure. 
Table 3: Cointegration Tests

\begin{tabular}{lcc}
\hline \multicolumn{1}{c}{ Relationship } & Engle Granger $\tau$ & Johansen trace \\
\hline Disposable income - GDP & $-5.46^{* * *}$ & $42.60^{* * *}$ \\
Corporate profits - GDP & $-4.37^{* * *}$ & $25.12^{* * *}$ \\
Total giving - GDP & -1.86 & $13.62^{*}$ \\
Individual giving - GDP & -1.87 & $14.01^{*}$ \\
Individual giving - disposable income & -2.08 & $36.50^{* * *}$ \\
Corporate giving - GDP & $-5.46^{* * *}$ & $33.84^{* * *}$ \\
Corporate giving - corporate profits & -2.65 & $15.59^{* *}$ \\
Foundation giving - GDP & -1.42 & $16.80^{* *}$ \\
$\begin{array}{l}\text { Bequests - GDP } \\
\text { Individual giving - GDP - tax price }\end{array}$ & $-3.66^{* *}$ & 11.88 \\
income tax & -2.95 & 21.46 \\
$\begin{array}{l}\text { Individual giving - disposable income } \\
\text { - tax price income tax }\end{array}$ & -3.19 & $46.00^{* * *}$ \\
$\begin{array}{l}\text { Corporate giving - GDP - tax price } \\
\text { corporate tax }\end{array}$ & -3.16 & $46.24^{* * *}$ \\
$\begin{array}{l}\text { Corporate giving - corporate profits - } \\
\text { tax price corporate tax }\end{array}$ & -2.76 & $28.38^{*}$ \\
$\begin{array}{l}\text { Bequest giving - GDP - tax price } \\
\text { estate tax }\end{array}$ & $-4.22^{* *}$ & 17.67 \\
$\begin{array}{l}\text { Total giving - GDP - tax price in- } \\
\text { come tax }\end{array}$ & -2.44 & 20.34 \\
\hline
\end{tabular}

Engle Granger: critical values from MacKinnon (1996), null hypothesis: single equation residuals are non-stationary; Johansen: critical values from MacKinnon, Haug and Michelis (1999), null hypothesis: no cointegrating relation. ***/**/*: Null hypothesis of no cointegration relationship can be rejected with significance level of $1 / 5 / 10$ per cent.

\section{Identifying elasticities}

In the following, the elasticities are measured based on an estimation of equation (4). This approach is applied to each sub-category of US giving and to total giving. For two giving subcategories a two-step procedure is workable since it is possible to define and quantify a potential giving base for these categories. In case of individual giving disposable personal income is the straightforward giving base since it determines the private households' capability to consume and donate.

In case of corporate giving profits could be an adequate giving base depending on the relevant underlying function of corporate giving. Two competing models exist in the literature in this 
regard (Clotfelter, 1985b; Boatsman and Gupta, 1996): Giving of corporations can either be understood as part of a profit maximization calculus where giving is an input to production which e.g. stimulates demand for a firm's products. Alternatively, it can be seen as an activity of managers' utility maximization for whom giving creates utility at the costs of owners. With managerial utility maximization being the relevant explanation one would expect a strong link to profits since then profit variation impacts on the available leeway of managers to distract resources from owner compensation. With profit maximization, however, one would rather expect a link to the corporation level of economic activity because like any other input factor, giving would be driven by the output level rather than by the issue of corporate profitability. Therefore, the two-step procedure is of particular interest in the case of corporate giving: If profits turn out to be the relevant giving base this points towards models of managerial discretion as the relevant ones for understanding charitable activities of the corporate sector.

For charitable bequests, the micro-evidence points towards the role of private wealth as the relevant giving base (Barrett, 1991; Joulfaian, 1991; Joulfaian, 2000). However, aggregates for US personal wealth are only available for some single years at the IRS Statistics of Income Division so that the time series necessary for inclusion in the testing does not exist. Therefore, the testing is limited to the one-step procedure which directly analyzes the link between charitable bequests and GDP. The same procedure applies to foundation giving where a quantification of a meaningful giving base is not available either.

Table 4 presents the first-step estimations for individual and corporate giving. These results reveal that corporate profits have a high short-run GDP elasticity of 3.29 whereas disposable income reacts inelastically (0.67). This difference still exists for the long-run elasticities although less drastic (long-run GDP elasticities amounting to 1.01 for disposable income and 1.46 for corporate profits). The much better regression fit for disposable income reveals that there is indeed a close link between GDP and disposable income while the GDP link is much looser for corporate profits.

Tables 5-9 include the regression results for the giving sub-components and total giving. For individual and corporate giving 2 × 2 specifications are tested: the second-step of the two-step procedure and the single-step estimation (i.e. the direct giving-GDP-link), each of them both including and excluding the tax price as an element of the cointegration relationship. For charitable bequests the analysis is confined to the one-step procedure including the estate tax price. For foundations due to their privileged tax treatment a tax price is irrelevant and not included. The total giving specifications are run with and without the income tax price. 
The key interest in the estimation findings is the measurement of giving elasticities. However, some observations on the overall regression results are telling. The comparison of the goodness of fit of estimation models results in considerable differences: For individual giving the one-step estimations which link giving directly to GDP tend to produce a better regression fit compared to the disposable income specification. The corporate giving estimations (Table 6) which relate giving to corporate profits (columns 3 and 4) fail to be well specified whereas the direct GDP related specification performs satisfactorily (columns 1 and 2). Corporate giving appears to be rather related to general economic activity than to corporate profits. This may indicate that giving of companies resembles the remuneration of a fixed factor of production which cannot be cut back in a situation of a sudden profit squeeze. Apart from that, the goodness of fit indicates a particularly poor performance of the error correction estimation for foundation giving (Table 7). This comes hardly as a surprise since the financing base of foundation giving - the foundations' capital receipts - should have a comparably loose link to GDP growth.

The inclusion of the tax price of giving into the dynamic modeling results in significant coefficients for individual giving under the disposable income specification (column 4 in Table 5) and for corporate giving under the GDP specification (column 2 in Table 6). The reaction of individual giving to the tax price appears, however, to be quite inelastic: The short-run income elasticity amounts to -0.16 and the long-run (missing to reach significance) to -0.30 . For corporate giving no significant short-run tax elasticity can be measured but the long-run elasticity is significant and amounts to -1.17 . For charitable bequests the short-run estate tax price elasticity is -0.70 but falls short of accepted significance levels, the long-run elasticity is of a similar magnitude (-0.84) and again misses significance. It is not surprising that the income tax price is insignificant for total giving given the mixed character of this aggregate and the differentiated incentives of different taxes for the sub-components of giving

\section{Short- and long-run elasticities}

Tables 10 and 11 summarize the findings on income elasticities. These elasticities are in the centre of interest since they inform about the growth-giving link. Before embarking on the detailed findings the different perspectives of the short- and long-run elasticities should be emphasized. The short-run elasticities are informative with respect to the immediate impact of GDP fluctuations on giving aggregates. Hence, they indicate to which extent business cycle 
fluctuations tend to destabilize the financing base of giving dependent activities. The long-run elasticities convey a very different message and illustrate to which extent the particular giving aggregate can benefit from the trend growth of an economy's available economic resources.

Comparing the short-run GDP elasticities across giving subcomponents (Table 10), corporate giving stands out to be highly elastic. However, the two-step decomposition reveals that the very high cyclical volatility of corporate profits does not translate into GDP-elasticity without substantial moderation. Individual giving fluctuates quite exactly in proportion to GDP developments if one takes into account the impact of the tax price on short-run dynamics. Foundation giving is not affected significantly by cyclical developments. For bequests, the only marginally significant negative elasticity hardly signals more than this aggregate's peculiarity results from the fact that death determines the timing of bequests rather than the business cycle. If one compares these finding on cyclical sensitivity with the knowledge of tax revenue volatility as a point of reference (Table 1) the patterns turn out to be comparable. Both corporate taxes and corporate giving are the most GDP-elastic component with the size of elasticity being similar (around 1.5 for taxes and between 1.6 and 2 for giving). Equally, the GDPelasticity of income tax revenues resembles that of individual giving. Giving as a whole is characterized by a GDP-elasticity not larger than one and is in this respect comparable to the cyclical properties of indirect tax revenues. Giving components detached from short-run fluctuations obviously compensate for the higher elasticity of corporate giving.

Long-run elasticities differ from the short-run dynamics with respect to foundation giving and bequests. These two giving sub-components benefit from long-run growth in a significant way although no significant positive short-run link to GDP exists. Interestingly, the point estimate for the long-run elasticity of foundation giving is the largest across all sub-components. The financing base of foundations appears to benefit substantially from US long-run growth. While individual long-run giving elasticities are of a similar magnitude as for the short-run, corporate long-run giving elasticities tend to be closer to the proportionate area than the shortrun ones. Giving as a whole is not significantly different from a 1.0-elasticity.

\section{Real growth elasticities}

So far, the analytical setting has dealt with growth without paying interest to the difference between inflation driven nominal growth on the one hand and real growth on the other hand. 
Therefore, the estimations are reiterated on the basis of deflated time series, using the GDP deflator. $^{7}$ The resulting elasticity estimates are summarized in Table 11 . While point estimates are somewhat larger than it is the case for the nominal estimates, the differences are not substantial with the exception of foundation giving. Foundation giving appears even more elastic if one concentrates on real growth processes.

Finally, the size of these macro-elasticities can be compared with the evidence from microstudies briefly surveyed in section 2. The macro view hints towards elasticities which tend to be above the average micro-estimates for individual giving. This difference must be interpreted with some caution due to the different character of approaches. However, this finding is consistent with the existence of social multipliers where the impact of growth on giving is reinforced by the mutual influence of individual households' and companies' giving. If this type of interaction exists, micro-approaches tend to underestimate the size of aggregate income elasticities. These findings stress that this might actually be the case for US giving.

Table 4: Giving bases and GDP

\begin{tabular}{|c|c|c|}
\hline & (1) & $(2)$ \\
\hline Dependent variable & $\begin{array}{l}\Delta \text { log } \\
\text { dispos. } \\
\text { income }\end{array}$ & $\begin{array}{l}\Delta \text { log } \\
\text { corporate } \\
\text { profits }\end{array}$ \\
\hline Constant & $\begin{array}{c}-0.16 * * \\
(-2.28)\end{array}$ & $\begin{array}{l}-1.29 * * \\
(-2.72)\end{array}$ \\
\hline$\Delta \log$ GDP & $\begin{array}{c}0.67 * * * \\
(8.52)\end{array}$ & $\begin{array}{l}3.29 * * * \\
(3.06)\end{array}$ \\
\hline $\log$ GDP(-1) & $\begin{array}{c}0.48 * * * \\
(3.98)\end{array}$ & $\begin{array}{l}0.25^{* *} \\
(2.48)\end{array}$ \\
\hline log dispos. income $(-1)$ & $\begin{array}{c}-0.47 * * * \\
(-4.06)\end{array}$ & \\
\hline Log corporate profits $(-1)$ & & $\begin{array}{l}-0.17 * * \\
(-2.04)\end{array}$ \\
\hline Number of observations & 40 & 40 \\
\hline Log likelihood & 133.39 & 29.69 \\
\hline F-statistic (zero slopes) & 78.43 & 3.75 \\
\hline Adjusted R-squared & 0.86 & 0.17 \\
\hline
\end{tabular}

t-statistics in parentheses, $* / * * / * * *$ : significance of 10/5/1 per cent.

\footnotetext{
${ }^{7}$ The results are robust to a replacement of the GDP deflator by the deflator for private consumption to derive a measure of real giving.
} 
Table 5: Individual giving estimations

\begin{tabular}{lcccc}
\hline & $(1)$ & $(2)$ & $(3)$ & $(4)$ \\
\hline Constant & $-0.79^{* *}$ & $-0.91^{* *}$ & $-0.76^{* *}$ & $-0.82^{* *}$ \\
& $(-2.18)$ & $(-2.33)$ & $(-2.20)$ & $(-2.36)$ \\
$\Delta \log$ GDP & $1.24^{* * *}$ & $0.98^{* *}$ & & \\
& $(3.51)$ & $(2.45)$ & & \\
$\log$ GDP(-1) & $0.17^{*}$ & $0.24^{* *}$ & & \\
& $(2.02)$ & $(2.28)$ & & $0.82^{*}$ \\
$\Delta$ log dispos. income & & & $1.07^{* *}$ & $(1.73)$ \\
& & & $(2.37)$ & $0.26 * *$ \\
$\log$ dispos. income (-1) & & & $0.18^{* *}$ & $(2.44)$ \\
& & & & $-0.16^{* *}$ \\
$\Delta$ log tax price & & -0.10 & & $(-2.10)$ \\
& & $-1.18)$ & & -0.07 \\
Log tax price (-1) & & -0.06 & & $(-1.30)$ \\
& & $(1.18)$ & & $-0.23^{* *}$ \\
log individual giving (-1) & $-0.15^{*}$ & $-0.20^{* *}$ & $-0.17^{* *}$ & $(-2.39)$ \\
\hline Number of observations & $(-1.87)$ & $(-2.19)$ & $(-2.08)$ & 40 \\
Log likelihood & 40 & 40 & 40 & 73.00 \\
F-statistic (zero slopes) & 73.42 & 74.55 & 70.33 & 3.57 \\
Adjusted R-squared & 6.69 & 4.41 & 4.02 & 0.25 \\
\hline
\end{tabular}

Dependent variable: $\Delta$ log individual giving, t-statistics in parentheses, $* / * * / * * *$ : significance of 10/5/1 per cent.

Table 6: Corporate giving estimations

\begin{tabular}{lcccc}
\hline & $(1)$ & $(2)$ & $(3)$ & $(4)$ \\
\hline Constant & $-3.03^{* * *}$ & -1.96 & -0.18 & 1.48 \\
& $(-3.22)$ & $(-1.66)$ & $(-0.83)$ & $(1.22)$ \\
& $1.63^{* *}$ & $1.29^{*}$ & & \\
$\log$ GDP(-1) & $(2.35)$ & $(1.80)$ & & \\
& $0.42^{* * *}$ & $0.54^{* * *}$ & & \\
$\Delta \log$ corporate profits & $(3.10)$ & $(3.26)$ & & $0.26^{* *}$ \\
& & & 0.17 & $(2.28)$ \\
$\log$ corporate profits (-1) & & & $(1.59)$ & 0.03 \\
& & & 0.06 & $(0.48)$ \\
$\Delta \log$ tax price & & -0.24 & & -0.28 \\
Log tax price (-1) & & $(-0.46)$ & & $(-1.25)$ \\
& & $-0.48^{*}$ & & -0.38 \\
$\log$ corporate giving (-1) & $-0.35^{* * *}$ & $-0.41^{* * *}$ & -0.07 & -0.00 \\
& $(-2.86)$ & $(-2.99)$ & $(-1.45)$ & $(-0.02)$ \\
\hline Number of observations & 40 & 40 & 40 & 40 \\
Log likelihood & 48.79 & 50.42 & 41.76 & 44.10 \\
F-statistic (zero slopes) & 7.27 & 5.05 & 1.56 & 1.84 \\
Adjusted R-squared & 0.33 & 0.34 & 0.04 & 0.10 \\
\hline
\end{tabular}

Dependent variable: $\Delta$ log corporate giving, t-statistics in parentheses, */**/***: significance of 10/5/1 per cent. 
Table 7: Foundation giving estimation

\begin{tabular}{lc}
\hline & $(1)$ \\
\hline Constant & $-0.78^{* *}$ \\
& $(-2.19)$ \\
$\Delta \log$ GDP & 0.19 \\
& $(0.28)$ \\
$\log$ GDP(-1) & $0.12^{* *}$ \\
& $(2.32)$ \\
$\log$ foundation giving (- & $-0.07^{*}$ \\
$1)$ & $(-1.72)$ \\
\hline Number of observations & 40 \\
Log likelihood & 48.22 \\
F-statistic (zero slopes) & 2.26 \\
Adjusted R-squared & 0.09 \\
\hline
\end{tabular}

Dependent variable: $\Delta$ log foundation giving, t-statistics in parentheses, */**/***: significance of 10/5/1 per cent.

Table 8: Bequests estimation

\begin{tabular}{lcc}
\hline & $(1)$ & $(2)$ \\
\hline Constant & $-1.79 * *$ & $-1.90^{* *}$ \\
& $(-2.45)$ & $(-2.62)$ \\
& $-2.73^{*}$ & $-2.00 * *$ \\
$\log$ GDP & $(-1.98)$ & $(-2.14)$ \\
& $0.33^{* * *}$ & $0.52^{* * *}$ \\
$\Delta$ log tax price & $(3.01)$ & $(2.89)$ \\
& & -0.70 \\
Log tax price (-1) & & $(-1.51)$ \\
& & -0.37 \\
log bequests (-1) & & $(-1.29)$ \\
& $-0.37 * * *$ & $-0.44 * * *$ \\
Number of observations & $(-3.47)$ & $(-3.80)$ \\
Log likelihood & 21.01 & 40 \\
F-statistic (zero slopes) & 4.25 & 22.66 \\
Adjusted R-squared & 0.20 & 0.22 \\
\hline
\end{tabular}

Dependent variable: $\Delta$ log bequests, t-statistics in parentheses, $* * * / * * *$ : significance of $10 / 5 / 1$ per cent. 
Table 9: Total giving estimations

\begin{tabular}{lcc}
\hline & $(1)$ & $(2)$ \\
\hline Constant & $-0.59^{* *}$ & $-0.68^{* *}$ \\
& $(-2.04)$ & $(-2.29)$ \\
$\Delta \log$ GDP & $0.97^{* *}$ & $0.72^{*}$ \\
& $(2.71)$ & $(1.75)$ \\
$\log$ GDP(-1) & $0.13^{*}$ & $0.20^{* *}$ \\
& $(1.91)$ & $(2.34)$ \\
$\Delta \log$ tax price & & -0.07 \\
& & $(-0.83)$ \\
Log tax price (-1) & & -0.07 \\
& & $(-1.35)$ \\
$\log$ total giving (-1) & $-0.11^{*}$ & $-0.16^{* *}$ \\
& $(-1.73)$ & $(-2.15)$ \\
\hline Number of observations & 40 & 40 \\
Log likelihood & 73.49 & 74.58 \\
F-statistic (zero slopes) & 4.76 & 3.23 \\
Adjusted R-squared & 0.22 & 0.22 \\
\hline
\end{tabular}

Dependent variable: $\Delta$ log total giving, t-statistics in parentheses, $* / * * / * * *$ : significance of 10/5/1 per cent.

Table 10: Short-run GDP and giving base elasticities

\begin{tabular}{|c|c|c|c|c|c|}
\hline & Individual giving & Corporate giving & Foundation giving & Bequests & Total \\
\hline$\varepsilon_{\mathrm{GB}}$ & $0.67^{* * *}$ & $3.29^{* * *}$ & - & - & - \\
\hline$\varepsilon_{\mathrm{G} \mathrm{GB}}$ & $1.07^{* *}\left(0.82^{*}\right)$ & $0.17\left(0.26^{* *}\right)$ & - & - & - \\
\hline$\varepsilon_{\mathrm{G}}$ & $1.24^{* * *}\left(0.98^{* *}\right)$ & $1.63^{* *}\left(1.29^{*}\right)$ & 0.19 & $-2.73^{*}\left(-2.99^{* *}\right)$ & $0.97^{* *}\left(0.72^{*}\right)$ \\
\hline
\end{tabular}

${ }^{+}$giving base measure: personal disposable income; ${ }^{++}$giving base measure: corporate profits. $\varepsilon_{\mathrm{G}} \mathrm{Y}$ estimated from one-step approach, hence not identical to $\varepsilon_{\mathrm{GB}}{ }^{*} \varepsilon_{\mathrm{G}} \mathrm{GB}$. In parenthesis: estimates for specification with tax price included. $* / * * / * * *$ : significance of $10 / 5 / 1$ per cent. 
Table 11: Long-run GDP and giving base elasticities

\begin{tabular}{|l|c|c|c|c|c|}
\hline & Individual giving & Corporate giving & Foundation giving & Bequests & Total \\
\hline$\varepsilon_{\mathrm{GB} Y}$ & $1.01^{* * *}$ & $1.46^{* *}$ & - & - & - \\
\hline$\varepsilon_{\mathrm{G} \mathrm{GB}}$ & $1.06^{* *}\left(1.14^{* *}\right)$ & $0.86(22.10)$ & - & & - \\
\hline$\varepsilon_{\mathrm{G}}$ & $1.10^{*}\left(1.17^{* *}\right)$ & $1.20^{* * *}\left(1.32^{* * *}\right)$ & $1.61^{*}$ & $0.87^{* * *}\left(1.17^{* * *}\right)$ & $1.14^{*}\left(1.25^{* *}\right)$ \\
\hline
\end{tabular}

${ }^{+}$giving base measure: personal disposable income; ${ }^{++}$giving base measure: corporate profits. $\varepsilon_{\mathrm{G}} \mathrm{Y}$ estimated from one-step approach, hence not identical to $\varepsilon_{\mathrm{GB}} \mathrm{Y}^{*} \varepsilon_{\mathrm{G}} \mathrm{GB}$. In parenthesis: estimates for specification with tax price included. Long-run elasticity calculated as ratio of coefficient of lagged exogenous (level) divided by lagged endogenous variable, multiplied by $(-1)$. */**/***: significance of 10/5/1 per cent for least significant coefficient in ratio.

Table 12: Short- and long-run GDP elasticities for inflation adjusted aggregates

\begin{tabular}{|l|c|c|c|c|c|}
\hline & Individual giving & Corporate giving & Foundation giving & Bequests & Total \\
\hline $\begin{array}{l}\varepsilon_{\mathrm{G}} \\
\text { short-run }\end{array}$ & $1.28^{* * *}$ & $1.99^{* * *}$ & $1.50^{* * *}$ & -1.11 & $1.12^{* *}$ \\
\hline $\begin{array}{l}\varepsilon_{\mathrm{G}} \\
\text { long-run }\end{array}$ & $1.18^{* *}$ & $1.34^{* * *}$ & $2.87^{*}$ & $1.23^{* *}$ & $1.32^{*}$ \\
\hline
\end{tabular}

Time series inflation adjusted by GDP deflator. Long-run elasticity calculated as ratio of coefficient of lagged exogenous (level) divided by lagged endogenous variable, multiplied by $(-1)$. */**/***: significance of 10/5/1 per cent for least significant coefficient in ratio. Underlying regressions obtainable from author.

\section{Conclusion}

With tax revenues as a point of reference, US giving constitutes indeed a relatively stable source of revenue. Total giving is characterized by a business cycle volatility which is comparable to the moderate one of indirect taxes. While giving thus by no means immunizes revenues from cyclical developments it does not feed an unusual volatility into the financing systems of the related activities. However, this overall finding is composed of the respective subcomponents' very different short-run GDP-elasticities. Whereas individual and in particular corporate giving is quite sensitive to cyclical fluctuations, foundation giving and charitable 
bequests tend to stabilize total giving over the business cycle. This cyclical buffer function of charitable bequests and foundation giving has so far been overlooked in the literature.

Beyond these results, the modeling approach offers the possibility to disentangle short- from long-run income elasticities. The former indicate to which extent business cycle fluctuations tend to destabilize the financing base of giving dependent activities. The latter inform to which extent the particular giving aggregate can benefit from the trend growth of an economy's available economic resources. Here the results for nominal (and even more for real) long-run growth paint a favorable picture: giving benefits in or even above proportion from an augmentation of economic resources in an economy. This holds for foundation giving in particular which is highly elastic to nominal and real long-run growth.

Further detailed results are to be underlined: The two-step approach, which takes account of a giving base as transmission channel, works much better for individual than for corporate giving. Disposable income has the character of a giving base for individual giving, while this is not the case for corporate profits in the case of corporate giving. The pattern of corporate giving resembles that of the remuneration for a fixed factor of production and thus is consistent with a profit maximizing view of corporate giving rather than manager utility maximization.

Finally, the comparison of the finding to the well researched micro-elasticities points to the possible existence of social multipliers in the case of US giving: the macro estimates for the income elasticities lie in the upper band of the micro-estimates. This is consistent with a social multiplier view according to which individual giving is mutually reinforcing. 


\section{References}

Alesina, A., E. Glaeser and B. Sacerdote (2005), Work and Leisure in the U.S. And Europe: Why So Different?, in: M. Gertler und K. Rogoff (Hrsg.), NBER Macroeconomic Annual, 1-100.

Andreoni, J. (1990), Impure Altruism and Donations to Public Goods - a Theory of WarmGlow Giving, Economic Journal 100 (401), 464-477.

Andreoni, J. and J.K. Scholz (1998), An Econometric Analysis of Charitable Giving with Interdependent Preferences, Economic Inquiry 36 (3), 410-428.

Auten, G.E., J.M. Cilke and W.C. Randolph (1992), The Effects of Tax Reform on Charitable Contributions, National Tax Journal 45 (3), 267-290.

Auten, G.E., H. Sieg and C.T. Clotfelter (2002), Charitable Giving, Income and Taxes: An Analysis of Panel Data, American Economic Review 91 (1), 371-382.

Barrett, K.S. (1991), Panel-Data Estimates of Charitable Giving: A Synthesis of Techniques, National Tax Journal 44 (3), 365-381.

Boatsman, J.R. and S. Gupta (1996), Taxes and Corporate Charity: Empirical Evidence from Microlevel Panel Data, National Tax Journal 49 (2), 193-213.

Borgloh, S. (2008), What Drives Giving in Extensive Welfare States? The Case of Germany, ZEW Discussion Paper No. 08-123.

Clotfelter, C.T. (1985a), Contributions by Individuals: Estimates of the Effects of Taxes, in: C. T. Clotfelter (Hrsg.), Federal Tax Policy and Charitable Giving. University of Chicago Press, Chicago, 16 - 99.

Clotfelter, C.T. (1985b), Corporate Contributions, in: C. T. Clotfelter (Hrsg.), Federal Tax Policy and Charitable Contributions. University of Chicago Press, Chicago, 171-221.

Clotfelter, C.T. (1985c), Foundations, in: C. T. Clotfelter (Hrsg.), Federal Tax Policy and Charitable Giving. University of Chicago Press, Chicago, 253-272.

Duquette, C.M. (1999), Is Charitable Giving by Nonitemizers Responsive to Tax Incentives? New Evidence, National Tax Journal 52 (2), 195-206.

Feldstein, M.S. and C.T. Clotfelter (1976), Tax Incentives and Charitable Contributions in the United States: A Microeconometric Analysis, Journal of Public Economics 5 (1-2), 126.

Frey, B.S. and S. Meier (2004), Social Comparisons and Pro-Social Behavior: Testing 'Conditional Cooperation’ in a Field Experiment, American Economic Review 94 (5), 1717-1722.

Girouard, N. and C. André (2005), Measuring Cyclically-Adjusted Budget Balances for Oecd Countries, OECD Economics Department Working Paper No. 434.

Glaeser, E.L., J.A. Scheinkman and B.I. Sacerdote (2003), The Social Multiplier, Journal of the European Economic Association 1 (2), 345-353.

Granger, C.W.J. and P. Newbold (1974), Spurious Regressions in Econometrics, Journal of Econometrics 2, 111-120.

Hendry, D.F. (1995), Dynamic Econometrics. Oxford University Press, Oxford, New York.

Jacobson, D.B., B.G. Raub and B.W. Johnson (2007), The Estate Tax: Ninety Years and Counting, Statistics of Income Bulletin (June), 118-128.

Joulfaian, D. (1991), Charitable Bequests and Estate Taxes, National Tax Journal 44 (2), 123123.

Joulfaian, D. (2000), Estate Taxes and Charitable Bequests by the Wealthy, National Tax Journal 53 (3), 605-605.

Joulfaian, D. and M. Rider (2004), Errors-in-Variables and Estimated Income and Price Elasticities of Charitable Giving, National Tax Journal 57 (1), 25-43.

MacKinnon, J.G. (1996), Numerical Distribution Functions for Unit Root and Cointegration Tests, Journal of Applied Econometrics 11 (601-618). 
MacKinnon, J.G., A.A. Haug and L. Michelis (1999), Numerical Distribution Functions of Likelihood Ratio Tests for Cointegration, Journal of Applied Econometrics 14, 563577.

McCaffery, E. and J. Baron (2005), The Political Psychology of Redistribution, UCLA Law Review 52 (6), 1745-1792.

Peloza, J. and P. Steel (2005), The Price Elasticities of Charitable Contributions: A MeteAnalyis, Journal of Public Policy \& Marketing 24 (2), 260-272.

Randolph, W.C. (2005), Charitable Deductions, in: J. J. Cordes, R. D. Ebel und J. G. Gravelle (Hrsg.), The Encyclopedia of Taxation \& Tax Policy, Second Edition. The Urban Institute Press, Washington D.C., 51-53.

Schiff, J. (1990), Charitable Giving and Government Policy: An Economic Analysis. Greenwood Press, New York.

Steinberg, R. (1990), Taxes and Giving: New Findings, Voluntas: International Journal of Voluntary and Nonprofit Organizations 1 (2), 61-79.

Tiehen, L. (2001), Tax Policy and Charitable Contributions of Money, National Tax Journal 54 (4), 707-723.

van den Noord, P. (2000), The Size and Role of Automatic Fiscal Stabilizers in the 1990s and Beyond, OECD Economics Department Working Papers, No. 230. 